\title{
Would the Employee Free Choice Act Effectively Protect the Right to Unionize?
}

\section{Evidence from a South Florida Nursing Home Case}

\author{
Bruce Nissen \\ Florida International University
}

\begin{abstract}
This article examines in detail union busting in a nursing home facility in Florida and asks whether the Employee Free Choice Act (EFCA) would have protected workers' freedom to choose if it had been in effect at the time. It systematically applies EFCA's provisions to the events of the case and concludes that EFCA would have been helpful to the workers. However, EFCA would not have erased all obstacles to free employee choice, especially for low-wage workers like these. It also reveals that one of the least known features of EFCA would have been most crucial in this case.
\end{abstract}

Keywords: Employee Free Choice Act; union organizing; antiunion behavior; union avoidance

D rivate-sector employer hostility to unions and union-avoidance behavior in the United States are nearly universal. Scholarly research documents the growth of union avoidance since the 1970s and explores alternative remedies for labor law failures but seldom details how "union-busting" campaigns occur in practice. Detailed accounts are usually news stories or nonacademic reports. Proposed remedies such as the Employee Free Choice Act (EFCA) are academically studied at a fairly abstract level. Seldom are EFCA's features applied to real-life union-busting campaigns to determine if they would protect workers' rights and enable union representation. This article attempts to address both deficiencies by examining in detail an example of fierce union resistance in a nursing home and analyzing the likely difference had EFCA been in effect at the time.

\section{Literature Review}

Scholars have long noted U.S. employers' hostility to unions and willingness to act on that hostility since the 1970s. Dickens (1983) documents the impact of employer behavior on union certification elections. Lawler $(1984,1990)$ analyzes the role of 
antiunion management consultants and examines the process by which companies "deunionize" themselves. Post-1960s antiunion employer behavior is documented in Freeman and Medoff (1984) and Kochan, Katz, and McKersie (1986). Kaufman and Stephan (1995) focus on the role of management attorneys in the antiunion effort. Nissen (1998) examines antiunion behavior in detail in an allegedly "union-friendly" employer. Kleiner (2001) relates antiunion employer behavior to the decline of U.S. union density. Logan's $(2002,2006)$ articles are most comprehensive in assessing the power and growth of the "union-avoidance industry" in recent decades.

Others examine union busting from a legal perspective. Weiler (1990) analyzes the failure and the future prospects of American labor law concerning employee representation. Bronfenbrenner (1994) documents employer oppositional behavior and shows the need for labor law reform. Comstock and Fox (1994) concentrate on needed legal reforms. Gross (1995) documents the transformation of the National Labor Relations Act (NLRA) from a protector of workers' rights into an instrument of employer coercion. Godard $(2002,2003)$ utilizes a comparative methodology to demonstrate the role of labor laws and institutional arrangements in determining union density.

The EFCA is a proposed legal remedy for what are seen as the worst failures of the current (NLRA) legal framework: employers' ability to utilize the NLRB "secret ballot" election process to intimidate and coerce (both legally and illegally) employees into union opposition; employers' ability to destroy unions by refusing negotiate a first contract with meaningful "union" features after union certification; lack of penalties sufficient to make illegal behavior unprofitable; and interminable delays in the administration of justice that often render it meaningless. EFCA would (1) provide for union recognition on the basis of "majority sign-up" or "card check" whereby verified signatures of a majority requesting union representation triggers automatic union certification; (2) mediate and arbitrate a first union contract if the two sides cannot bargain one within ninety days; (3) provide for treble back pay (rather than simple back pay) for employees illegally fired for union activities in a union organizing drive or before a first contract is achieved, as well as penalties up to $\$ 20,000$ per employer violation in cases of willful or repeated violations; and (4) require the NLRB to assign the highest priority to investigations of possible employer interference with employees' rights during a union organizing campaign, thus speeding up the process of justice and potentially allowing for injunctions if necessary to prevent employer misconduct.

Most scholarly attention to EFCA has focused on majority sign-up or card check as a union certification procedure. Eaton and Kriesky (2001) demonstrate that employees feel less coerced and better exercise their free will when employers agree to neutrality in an organizing campaign and accept the card check procedure. Brudney (2005) argues that the older "NLRB secret ballot election" paradigm can no longer be justified as the main avenue to union recognition; the majority sign-up paradigm shows greater regulatory promise. Stewart (2006) argues that card check as provided by EFCA would violate the sanctity of the secret ballot election and 
deny employees their rights to indicate their preferences in secret. Lafer (2008) documents the failure of the NLRB secret ballot election process to meet elementary standards of fair electoral process and shows the majority sign-up process to be more democratic.

Adams (2007) questions whether EFCA will actually benefit U.S. unions much in light of the Canadian experience and proposes an alternative. Friedman (2007) argues in reply that EFCA will address the most important impediments to union organizing success, even if it will not correct all of them. Martinez Ortega (2007) likewise defends EFCA and argues that Adams's alternative would be weak and ineffective.

Most scholars pay little attention to actual cases of union busting, and few arguments about the EFCA utilize case-study evidence. Yet the merits of this proposed piece of legislation can best be determined by close empirical evidence of how it would impact actual situations. This article attempts to do just that.

\section{Methodology and Initial Hypothesis}

This research is an in-depth, longitudinal examination of a particular event, a unionization attempt by nursing home workers in south Florida in the 1990s and the employer's opposition to that attempt. As such, it is a retrospective case study. The following sources of information were used: union files on the case, including letters, faxes, notes, interviews, organizer reports, lawyer communications, press releases, and the like; NLRB decisions and communications; news accounts; union official interviews; testimony from an affected employee; discussion with the lead union organizer; and records of the state's Agency for Healthcare Administration. To avoid bias due to union-side sources, NLRB findings are generally relied upon to determine truthfulness. The case is written descriptively, chronologically detailing events as they unfolded.

A single case cannot easily be generalized, but this case study does not claim that all union-busting campaigns will follow the trajectory of this particular one. Rather, the case is used to test claims and counterclaims made about the efficacy of EFCA in curbing union-busting employer behavior when workers attempt to exercise their freedom of choice regarding a union. Case studies are particularly appropriate for confirming or disconfirming theories, hypotheses, or claims, since even one contrary instance calls a claim into question. Analysis of the case asks, how would the case have come out differently had EFCA been in place at the time it took place? On the basis of previous research, it is hypothesized that EFCA's features would have greatly aided the workers in their effort to unionize, had they been present in this case.

\section{Background}

The King David Nursing Home in West Palm Beach, Florida, was an acute-care, long-term facility with many residents with mental disabilities such as dementia or 
Alzheimer's disease. Certified Nursing Assistants (CNAs) provided patient care, working under the direction of Registered Nurses (RNs) or Licensed Practical Nurses (LPNs). Together with CNAs, dietary, housekeeping, and laundry service workers at King David earned between $\$ 6.00$ and $\$ 9.00$ per hour in the early 1990s. A very large percentage of the nonprofessional workforce at King David was Haitian American.

\section{Early Union Stirrings}

In July 1993, some King David employees became aware of and contacted the nursing home union in south Florida (then known as Local 1115 of the Service Employees International Union [SEIU] and now known as SEIU Florida Healthcare Union). Concerned about low pay, understaffing, and a perceived lack of respect from management, they set up an organizing committee, including Ernest Duval, his wife Lude Duval, Pierre Exile, Carline Dorisca, Michelle Williams, and others. After clandestine organizing, in late December 1993 and in January 1994, the union began openly holding meetings and distributing union buttons. Housekeeping and laundry work at King David were contracted to a business called Healthcare Services Group. Therefore, the union had to file separate petitions (on January 25 and January 28) for two union representation elections conducted by the NLRB.

\section{Antiunion Campaign Begins}

In early January 1994, nurse supervisor Celina Caprisecco noticed employee Jean Aliza wearing a union button and asked what it was. He told her she could read it to understand what it was, and she angrily walked away. An NLRB hearing officer later found that from that day on, Caprisecco inspected Aliza's work more closely than previously, looking for possible faults (PVMI Assocs., 1996 NLRB LEXIS 94 [N.L.R.B. Feb. 29, 1996] [Batson, J.]).

On January 28, the facility's Director of Nursing Betty Whelan and its Quality Assurance Director, Whelan's daughter Lisa Megill, confronted employee Luders Esteril about his possible involvement with the union. Repeated questioning forced from him an admission that he had signed a union petition. The following week, Megill questioned Ernest Duval about his union button and emphatically expressed disapproval when he affirmed his support for the union. Later that day, Megill called Duval to the office and gave him a written warning for alleged work deficiencies. Duval protested that the warning was due to his union support, not his work performance. Whelan then tore up the written warning and told Duval that "everything is now fine." An NLRB hearing officer later found this "good cop" (Whelan)-“bad cop" (Megill) routine to be part of a pattern of intimidation of Duval for his union support (PVMI Assocs., 1996 NLRB LEXIS 94). 
On February 9, 1994, Caprisecco and Megill placed a written warning for unsatisfactory work performance in Jean Aliza's personnel file without his knowledge. On February 11, Caprisecco created another (unknown to Aliza) written warning to Aliza for alleged rudeness. Caprisecco later claimed that on February 23, she found Aliza unwilling to help move a patient and counseled him for unsatisfactory work performance; again, the alleged incident and counseling were unknown to Aliza. The next day, Megill and Caprisecco claimed to find a sandwich in the drawer of one of Aliza's patients and accused him of negligence. On February 25, they fired Aliza for poor work performance. An NLRB hearing officer found this entire sequence to be a "setup" of Aliza to fire him because of his union support (PVMI Assocs., 1996 NLRB LEXIS 94).

Whelan and Megill told a February 10 mandatory meeting of CNAs that they could vote for the union if they wished, but any of them could be fired at any time. Their only hope for continued employment was to do their job without any mistakes because they could be dismissed, union or no union. This was subsequently found to be an illegal threat (PVMI Assocs., 1996 NLRB LEXIS 94).

In mid-February, Megill threatened employee Marie LaRose that she would be fired if she did not take off her union button. LaRose testified that Megill stated, "I fire you if you no take the pin off" (English was LaRose's second language, explaining the poor English). LaRose refused to do so. Shortly thereafter, she was reduced to part-time status, and in late May, she was fired. An NLRB hearing officer later found this sequence of events to be a coercive and discriminatory violation of the NLRA (PVMI Assocs., 1996 NLRB LEXIS 94).

At a February 22, NLRB hearing to determine proper "bargaining units" for union representation, employee Carline Dorisca testified for the union. The next day, she was interrogated by the only Haitian Creole-speaking management person, Yves Waterman, concerning her union testimony. The same day, Waterman threatened Lude Duval with reprisals for wearing a union pin and asked about her husband's union support. He stated, "Mrs. Duval, you can be in trouble." This was subsequently found to unlawful interrogation and an illegal threat to retaliate for union activities (PVMI Assocs., 1996 NLRB LEXIS 94).

On March 16, Megill gave Lude Duval a written warning for drinking a glass of water on the job. Later, she called Duval at home to say that her husband gave the nursing home "too much trouble." She then changed Lude Duval's schedule to five single shifts per week from her previous two double shifts plus a single one, which she needed to care for her children. Megill asked Duval, a two-year employee, if she had a Florida CNA certificate. Duval answered no, but she was about to take an RN certification test. She had a three-year European college degree and had worked as an RN in Belgium and under special license for five years in a New York hospital. She was allowed to continue CNA work pending proof of her upcoming RN exam.

Megill repeatedly pressed Duval about the results of her RN test. On April 20, Duval told Megill that she had failed the test and, the next day, was fired for lacking 
the necessary CNA certification. Nursing home administrators later admitted that Lude Duval had a spotless record as a CNA, was one of the best CNAs they knew, and previously, had no disciplinary problems. They also admitted that Joyce Neloms, an antiunion CNA without the CNA certificate, who had testified for the employer at hearings, was allowed to stay on in a capacity other than direct nursing care until she obtained her certificate. In June, Lude Duval received CNA certification, sent her certificate to the nursing home, and requested immediate reinstatement but was never offered a job. The NLRB hearing officer later found this pattern of behavior to be illegal retaliation against Duval for her and her husband's support for the union (PVMI Assocs., 1996 NLRB LEXIS 94).

\section{Employer Support for an Alternative So-Called Union}

At NLRB hearings on March 14 and 15, 1994, to determine whether there would be two bargaining units or one in the union election, a man named Jeffrey Metzger made a surprise appearance representing the International Union of Industrial Service Transport and Health Employees District 6 (hereinafter "District 6"). District 6 is an independent union not affiliated with the AFL-CIO that represents workers in industries along the eastern U.S. seaboard, primarily healthcare workers and airport skycaps. This union presented two signed union authorization cards and claimed an interest in representing employees at King David. It is unclear if District 6 is a legitimate independent representative of workers or a "union" that is simply a cover for more corrupt aims. U.S. Department of Labor records show that from 1993 to 1999, more than \$1 million was being embezzled from District 6's pension fund and its health and welfare fund (U.S. Department of Labor 2002; U.S. Department of Labor 2004).

On June 17, the NLRB decided that there would be two bargaining units and two simultaneous elections on August 5. CNAs and dietary workers employed by King David would be one group, and a smaller unit of housekeeping and laundry workers employed by Healthcare Services Group would be the other. District 6 was allowed on the ballot for the King David unit due to its two signed authorization cards.

In the final week of June, King David allowed Metzger into the facility to talk to CNAs and give out free donuts during breaks to convince them to vote for District 6. On July 2, 1994, King David supervisor Gretza Matses introduced Metzger to a mandatory meeting for all CNAs and asked him to explain the advantages District 6 representation. Metzger advocated District 6 as a representative of the nursing home's CNAs.

Learning of this "captive audience speech" (i.e., speech that employees were required to attend during working hours) addressed by a rival union, on July 7, SEIU requested equal time to address the workers on the job. Because employers are not allowed to favor one union over another (such as a "company union" over a genuine one), equal time is required but was not allowed to the SEIU. An NLRB hearing 
officer later found this to be illegal favoritism of one union over another (PVMI Assocs., 1996 NLRB LEXIS 94).

\section{Continued Preelection Antiunion Threats, Surveillance, and Harassment}

In May, the nursing home posted a new rule forbidding employees to speak Haitian Creole in the presence of patients. The employer later claimed that an "in-service" training on the new rule was conducted on June 18, but their proof was an altered document showing an attendance signature of an employee, Jean Aliza, who had been fired almost four months earlier (brief written by the NLRB general council to ALJ Batson [hereinafter "NLRB general council brief"], June 26, 1995; copy in the author's possession). The "No Haitian Creole" rule would later be used to harass union supporters both before and after the August union election.

In early July 1994, CNA Ernest Duval noticed a patient (not in his area of duty) on the floor lying in a pool of urine. He immediately solicited the assistance of nearby supervisor Art Dryer. Duval and Dryer placed the patient in a geriatric chair, and Duval requested the housekeeping staff to clean up and returned to his own patients. Dryer subsequently claimed that fifteen minutes later, this patient was in a urine-soaked bed trying to get out. Megill, Caprisecco, and Dryer then gave Duval a written disciplinary warning because of the patient's condition. The CNA actually responsible for this patient was not punished. Duval refused to sign the written discipline, noting that it was not his patient.

Two days later, Duval and an LPN named Audrey White cleaned, bathed, and diapered a patient whose last name was Herman after a bowel movement. Duval then went to care for a patient in another room. Five minutes later, Dryer violently knocked on the door of the room Duval was in, entered, demanded that Duval immediately come to Herman's room, and claimed that Herman was filthy and wet. Duval went to Herman's room, found him wet from stomach to toe, but the liquid had no odor of urine and appeared to be plain water. Suspecting a "setup," Duval called in LPN Audrey White, who confirmed that the wetness was not urine. After drying and reclothing patient Herman, Duval complained to management about the setup attempt.

On July 21, 1994, union organizer Marie Jean Phillippe and two other union organizers held a meeting at a nearby Pizza Hut with CNA Michelle Williams. Phillippe recognized Megill and Caprisecco sitting five feet away, as close as possible to the meeting. From 1:30 p.m. until 2:55 p.m., Megill and Caprisecco, allegedly there for lunch, received no food but drank coffee and smoked cigarettes. Megill and Caprisecco later testified that they planned lunch, but the waitress had forgotten to turn in their orderthey just happened to sit for one and a half hours as close as possible to the union meeting. An NLRB hearing officer later ruled this to be illegal surveillance but was overruled by the national NLRB members, who voted two to one that the one-and-a-half-hour 
proximity without an ordered lunch could be coincidence (PVMI Assocs., 1996 NLRB LEXIS 94; PVMI Assocs., 328 N.L.R.B. 1141 [1999]).

In early July, supervisor Yves Waterman asked CNA Quettelie Jean-Baptiste in Haitian Creole where she got her union button. She replied in English, "The union," and he asked, what is the union going to do for you? She ignored his remark and continued to work. Approximately a week and a half later, Waterman told Jean-Baptiste that the union would do nothing for the CNAs. He continued that "Lisa Megill had a list of names and knew who would be voting for the Union, continuing that those who did not vote for the Union would be covered, but those who voted for the Union would get in trouble, "They will be fired"' (PVMI Assocs., 1996 NLRB LEXIS 94, *46). This conduct was later to be found to be illegal threats and illegal creation of the impression of surveillance (PVMI Assocs., 1996 NLRB LEXIS 94).

One week before the August 5 election, CNA Pierre Exile received a phone call at home from Lisa Megill telling him to vote "no" and to stop by her office on election day prior to voting. He did so and was grilled by Megill, Whalen, and Waterman about his voting intentions. Exile promised to vote "no" even though he voted "yes," according to his later testimony. After the election, Exile, an assistant pastor at a church, was forced to work Sundays, stressing him to point of quitting by October.

Also, in late July, supervisor Yves Waterman threatened to "write up" CNA Quettelie Jean-Baptiste and another CNA at 11 p.m. as they were leaving work. He threatened a three-day suspension for failing to respond to a patient's "call light" on the first floor, an area for which Jean-Baptiste was not responsible. The next day, Megill played the "good cop" and ripped up the warning. This incident combined with Waterman's earlier threat to Jean-Baptiste about the alleged list of union sympathizers created the circumstances for an "anxiety attack" by Jean-Baptiste, to be related later.

In late July, Ernest Duval spoke on a Creole-language radio program along with union organizer Marie Jean Phillippe urging King David workers to vote for the union. From this point forward, management steadily escalated the campaign against him that had begun with the February "good cop-bad cop" routine and two attempted "setups" earlier in July. Four days before the August 5 union representation election, Megill gave Duval a disciplinary warning for alleged unsatisfactory performance and told him that he would receive such a warning every day; after three warnings, he could be fired. (Ironically, Megill had valued Duval so much prior to the organizing drive that she had requested he move with her from another nursing home to King David because of his work ethic.) On August 3, Caprisecco gave Duval another written warning for allegedly speaking Creole. Duval protested that he had not spoken Creole but had merely waved to a Haitian lady from about twenty feet away. An NLRB hearing officer later found Duval's testimony to be the only credible account of what actually happened (PVMI Assocs., 1996 NLRB LEXIS 94).

The evening before the August 5 election where Duval was to be a union observer of the polling, he called his shift supervisor Susan Fagan to report that he would be 
unable to work the next day. Asked if he was sick, he answered no and began to explain, but Fagan cut him off because she was so busy and ended the conversation.

\section{Union Election Victory and Retaliatory Aftermath}

On Friday, August 5, the union representation election was held. Of the 104 eligible King David workers, 85 attempted to vote. Five ballots were challenged for ineligibility, two votes were voided for technicalities, and seventy-eight valid ballots were counted. The final tally was forty-eight votes for SEIU, twenty-nine votes for no union, and one vote for District 6. The union also won the Healthcare Services unit of housekeeping and laundry workers.

When Ernest Duval reported to work on Monday, August 8, Art Dryer asked him to sign a written disciplinary warning for rudeness to Susan Fagan during the August 4 phone call. Duval denied any rudeness, and management refused to bring in Fagan for confirmation. Duval didn't sign and later asked Fagan if she thought he had been rude. Fagan told him that she had no problem with him but that "Mrs. Whelan just got her own problem with you." Fagan gave no further explanation (PVMI Assocs., 1996 NLRB LEXIS 94).

Later the same day, supervisor Art Dryer accompanied Duval to visit all his patients. Much to Duval's surprise, many of his patients' "call lines" (push-button electrical lines to signal the nurses' station for help) had been moved far from his patients, onto the floor or away from these bedridden patients. Duval was called to the front office, where Megill wrote him up for improper placement of call lines. Duval stated, "This is a 'set-up', and I'll bring charges against you" (PVMI Assocs., 1996 NLRB LEXIS 94).

On Saturday August 13, supervisor Gretza Matses wrote up Duval for not being at his work station as he was heading there after clocking in. The following morning, Matses explained that she had to get something on Duval before the weekend was up or else she (Matses) could lose her job. Matses stated that she had a daughter to support, noted that she had no problem with Duval, but she had to protect her own job.

That same day, Matses got into a heated dispute with a male CNA, alternately named Janno or Janot Lorius in written accounts, over where he parked his car. Lorius allegedly made a death threat against Matses, who called the police. Lorius was removed from the facility and given a two-week suspension. According to the police report, Matses also said that she felt intimidated by Ernest Duval although he had not made any threats. The following day, Duval was fired for threatening Matses. In later testimony, before an NLRB hearing officer, Matses contradicted all the facts stated in the police report of the incident by claiming that it had been Duval, not Lorius, who had threatened her and that was why he was fired. The NLRB hearing officer found her to be lying to justify the firing of Duval (PVMI Assocs., 1996 NLRB LEXIS 94). 
Others were also being pressured and threatened. At a meeting the day before the election, Megill had threatened to end the previous practice of granting accommodations to employees regarding work schedules, weekend schedules, and the like would end if the union came in. Everything would be "by the book" with no more special schedules.

In mid-July, original union organizing committee member and strong union supporter Carline Dorisca had requested a special schedule consisting of two double shifts plus a single shift so that she could attend school. Immediately after the meeting mentioned in the previous paragraph, she asked Megill what this meant for her, and Megill assured her that her request would still be approved. On August 6, the day after the union victory, Megill told Dorisca that her request was denied. Shortly thereafter, Dorisca and other CNAs were cut back on hours, ostensibly due to overstaffing.

Ultimately, Dorisca shared Duval's fate: illegal discharge. About November 23, 1994, supervisor Susan Fagan told Dorisca that Megill had told her to postpone a recommended pay raise for Dorisca. Dorisca later testified that on December 5 new supervisor Mary Walgousse warned her and another CNA that Art Dryer had hired new CNAs for the 11 p.m. to 7 a.m. shift with the intent of firing incumbent CNAs because of the union, so they'd better watch out. Two days later, Dorisca was fired.

On December 7, Assistant Director of Nursing Dorrett Waterman claimed that she discovered patient Virginia Reynolds in bed wet and covered with feces at 8 a.m. Dorisca had been the CNA in charge of this patient on the 11 p.m. to 7 a.m. shift. Waterman claimed that the feces were dry, so the soiling must have happened on Dorisca's shift, and told Walgousse to fire Dorisca for patient neglect, which she did. Dorisca testified that at 6 a.m. that day, she had attempted to get a urine sample from patient Reynolds, leaving the bed pan under her for ten minutes with no success. She reported this to the head nurse who said the next shift would get the sample. Dorisca then cleaned the patient, made the bed, left ice for the patient, and clocked out at 7 a.m.

The day shift CNA between 7 a.m. and the 8 a.m. discovery of the patient was Joyce Neloms, an antiunion employee who had testified for the company in hearings. Her first duty was to check on all the patients after checking in. Patients were fed breakfast at 7:30 a.m. Neloms had not discovered the feces on either occasion but faced no punishment while union activist Dorisca was fired on the theory that the soiling may have occurred earlier during her shift. An NLRB hearing officer later found this firing to be due to Dorisca's union activities and thus illegal (PVMI Assocs., 1996 NLRB LEXIS 94).

Union leader Luders Esteril also faced retaliation and dismissal. Five days after the election, Megill, Caprisecco, and Dryer issued a written warning to Esteril for alleged work deficiencies. That same day, Esteril asked for permission to take time off on August 20 and 21 for other pressing obligations. Megill said they both should look to find a replacement and gave the same response when Esteril put request in writing on August 16. The facility was laying off workers and shortening CNA work hours (as retaliation for the union election victory, the union claimed), so replacement 
labor on the 20th and the 21 st could easily be found, as had been done during previous requests for time off.

Megill made no effort to find a replacement, contrary to previous practice. Esteril took the 20th and 21st off and was written up upon return for being a "no-call, no-show" even though Megill admitted it may have been a misunderstanding. Threatened that one more instance would result in dismissal, Esteril became very alarmed and decided to take a day off to calm his nerves. The next morning, he called at 5:00 a.m. to report that he would not be at work and left a message when told that his supervisor was busy. The next day, he was fired by supervisor Art Dryer for not calling in.

Esteril had previously been noted as a union supporter. In January and July, Whelan and Megill had tried to get him to oppose the union. His wife had been warned that she and her husband's union support caused the nursing home too much trouble. The NLRB hearing officer later found that King David fired Luders Esteril because of his union activism while using the call-in issue as a pretext ( $P V M I$ Assocs., 1996 NLRB LEXIS 94).

Following threats and write-ups in July, Quettelie Jean-Baptiste was given a written warning on August 13 for speaking Creole with a fellow CNA in the kitchen out of hearing range of any patients. She was told that one more instance would result in dismissal. On the same day, she was reassigned from her regular work assignment of two and a half years to the acute-care division where she was unfamiliar with the patients.

On Sunday, August 14, Jean-Baptiste buckled under the strain: she had an "anxiety attack" and fell writhing to the ground while hyperventilating. Her husband Emmanuel Jasney and paramedics were called to the scene. She was administered oxygen to aid in breathing. Jasney pleaded with paramedics to take his wife to the hospital, but they refused, and eventually, he drove her there himself. A physician saw her and released her.

The following day, the Director of Nursing Betty Whelan refused to allow JeanBaptiste to return to work until she had a physician's statement certifying that she was mentally and physically able to work. Within a week, Jean-Baptiste produced such a note and went back to work, although she lost a week's pay because of this delay. ${ }^{1}$

Original organizing committee member and union supporter Michelle Williams was next. Williams, a highly visible union supporter who had testified for the union and who wore an insignia identifying her as a union steward, had been told in midJuly by supervisor Yves Waterman that the union was no good and that she should remove her union button and stop talking about the union. He then made a motion as if to physically remove her button, although he did not touch her. The day before the election, Williams had called in sick. When she voted on August 5, Megill and Whelan were incensed that she appeared to be in no discomfort. The next day, Megill wrote her up for excessive absenteeism, particularly her absence the day before the election. A week later, she was written up for allegedly not doing sufficient work in the first half hour of her shift. 
On November 11, Director of Nursing Whelan fired Williams for excessive absenteeism and for "giving out information." A four-year employee, Williams had a problematic attendance record. She had been absent while calling in nineteen times in 1992, seventeen times in 1993, and fourteen times in 1994 up until her firing. Despite her poor attendance record, unequal enforcement against a high-profile union steward after the union electoral victory convinced an NLRB hearing officer that this was a retaliatory firing for union activities. Antiunion CNA Joyce Neloms had been absent twenty-two times in 1993 and had been out at least twelve times in 1994, yet she received no punishment (PVMI Assocs., 1996 NLRB LEXIS 94).

Williams was also accused of "giving out information" to a local newspaper about the death of a patient that led to a highly critical news story. The patient had never been under Williams care; Williams denied speaking to the newspaper reporter, and Whelan could not explain why she suspected Williams as the source. The NLRB hearing officer also found this to be a pretextual excuse for the firing (PVMI Assocs., 1996 NLRB LEXIS 94).

Marie Pierre Louis, another well-known union supporter, was the next victim of the retaliatory campaign. In early October, her new supervisor Mary Walgousse confidentially warned her. According to an NLRB finding, "Walgousse told Pierre Louis that she was doing a good job but that she needed her to do an even better job. The reason she needed her to do a better job was that Lisa Megill had told her every CNA on the 3:00 to 11:00 shift was for the Union. She continued to the effect that Megill had indicated they were looking for a reason to get rid of them" (PVMI Assocs., 1996 NLRB LEXIS 94, *75). The warning followed postelection reduction in the number of CNAs in this area on this shift from six to four and reduction of Pierre Louis's workweek from five to four days.

On November 8, Walgousse claimed that a patient had complained that a CNA had refused to take her to the bathroom. The patient could not identify which aide it was. Walgousee then took two CNAs to the room and stated that the patient then identified Pierre Louis as the aide in question. The following day, Walgousse fired Pierre Louis, apologetically stating that she knew Pierre Louis was a good worker but that Megill had left a note stating that Pierre Louis had to be fired because of the alleged bathroom incident, which Pierre Louis denied ever happened. An NLRB hearing officer later found this to be a pretextual firing, noting that many of the patients had Alzheimers or dementia and that no full investigation was conducted to discern the actual truth of the matter. He also noted that more serious infractions, such as accusations of slapping a patient, had resulted in much less drastic punishment (PVMI Assocs., 1996 NLRB LEXIS 94).

By mid-November 1994, slightly over three months after the union election, the employer had fired thirteen employees, well over 10 percent of the facility's CNAs, and had removed all of the union's strongest supporters. Hours and working conditions had worsened and known union supporters were followed and constantly spied upon. The message to the workers was that association with the union could mean 
loss of one's livelihood and certainly meant harassment and unpleasant, conflictladen working conditions on the job. The intimidation eventually broke the spirit of the workforce, and workers lost an independent voice at the workplace by the end of 1994. Much of the rest of this tale shifts to the second element of the antiunion campaign, legal maneuvering.

\section{Legal Maneuvering and Indefinite Delays}

Accompanying its worksite "reign of terror," King David began a legal battle to defeat the will of its employees as expressed in the August 5 election. Both King David and contractor Healthcare Services filed objections to overturn the elections in early August, thus ensuring no union recognition or bargaining until legal matters were settled.

The simpler tale concerns King David's housekeeping and laundry contractor Healthcare Services, which objected to the election on August 11, 1994. The NLRB swiftly rejected the objections, and the union was certified as the legal representative of the housekeeping and laundry workers on September 12, 1994. On October 24, Healthcare Regional Manager William Wolfe met with union officials and received their wage and benefit proposals but gave none of his own. Contacted on November 10 about future negotiations, according to the union's attorney, Wolfe stated that "he can't give us a contract without the other unit [King David bargaining unit of CNAs and related personnel-BN] being certified ... if he gave us a contract, the client would find some excuse to fire them, that their contract with King David would be terminated" (NLRB general council brief, June 26, 1995).

Healthcare's president Dan McCartney affirmed that they would lose their contract if they gave a contract and refused any further bargaining sessions. On November 25, the union filed a complaint with the NLRB, charging Healthcare with a refusal to bargain with a certified union, an illegal "unfair labor practice" (ULP) in NLRB language. In January, Wolfe informed the NLRB and the attorney who had filed the NLRB charges (but who was no longer working for the union) that he was willing to bargain but made no attempt to contact the union or to initiate bargaining.

During February and March of 1995, NLRB hearing officer (known as an Administrative Law Judge or ALJ) Robert Batson heard testimony on Healthcare's failure to bargain, employee harassment, surveillance, discrimination, threats, firings, and the like. Complicated legal maneuvers and a massive volume of issues meant that Batson was unable to rule on the failure-to-bargain charge until February 29, 1996. He ruled that Healthcare had violated the law by refusing to bargain and ordered it to recognize the union and to bargain. From 1996 on, Healthcare followed the lead of King David and avoided substantive bargaining through a variety of means to be related below. 
King David pursued a more aggressive antiunion legal strategy. Their retaliatory measures and thirteen firings prompted numerous union legal complaints to the NLRB. In the second half of 1994, the union had to file or amend/refile/consolidate ULP charges fourteen times, utilizing much lawyer and staff time.

King David's legal strategy was to appeal every adverse ruling indefinitely. If the NLRB attempted to consolidate charges or to sever cases in the interests of expediting the process, King David's lawyers would appeal that too. Tactics like this slow the process to almost a standstill because there are three levels of the NLRB apparatus to which one can appeal (the ALJ, the regional office, and the national office), followed by appeal to the U.S. courts for as long as that process can be played up to the level of the U.S. Supreme Court.

The February and March 1995 hearings before NLRB ALJ Robert Batson lasted fifteen days and featured over forty people testifying; the resulting transcript was 2,900 pages long. Issues were (1) Healthcare's refusal to bargain following the union's legal certification (related earlier), (2) King David's and District 6's objections to the conduct of the election and their request to overturn its results, and (3) the many ULP charges filed by the NLRB general counsel charging King David with illegal threats, discrimination, harassment, firings, and so on, against individual employees.

Both King David and unsuccessful "union" District 6 asked that election results (SEIU: 48 votes; District 6: 1 vote; no union: 29 votes) be nullified due to election misconduct. District 6 alleged that an NLRB hearing officer at a February 1994 hearing had mentioned its two signed union authorization cards publicly, irreversibly tainting the election. While the number of signed cards is supposed to be secret, ALJ Batson ruled that this technical error was not enough to invalidate the election absent evidence it had influenced any workers. District 6 also alleged that SEIU had provided workers free housing in exchange for their votes but offered no evidence, and the charge was dismissed.

King David made three allegations against the union: (1) it had appealed to racial and ethnic prejudices, including threats of voodoo, to coerce workers into voting for the union; (2) its agents had posed as Federal Express or delivery service employees in order to improperly gain entrance to the homes of King David employees; and (3) it had made threats of bodily harm and death to employees if they did not vote for the union.

The sole evidence for the first charge was that SEIU union organizer Marie Jean Phillippe and King David employee Ernest Duval had appeared on Haitian talk radio urging employees to vote for the union because it would improve their lives and get them good benefits, while noting that Haitian American supervisor Yves Waterman treated some employees badly. On the second charge, one worker stated she was visited at home by people who were probably (never determined exactly) from the union after earlier receiving an unidentified call asking her exact address to deliver 
a package. No clear connection was established between the two events. Evidence for the third charge was testimony from a CNA employee that when she declined Ernest Duval's request to wear a union button, he stated that he would not try to force her, but if the union did get in, she would be in "big trouble." King David argued that this was somehow a death threat.

In an August 3, 1995, ruling, ALJ Batson summarily dismissed all these charges and ruled the election valid, thereby certifying SEIU as the employees' representative at King David. On November 1, 1995, the NLRB accepted Batson's ruling as final and certified the union at King David. Thus, fifteen months after the election, the union was supposedly officially certified, but further legal maneuvers further delayed recognition.

\section{Ruling to Reinstate Fired Workers, Followed by More Delays}

By February 29, 1996, almost a year after he had held the hearings and six months after he had certified the union, ALJ Batson had waded through the 2,900 pages of testimony from the hearings and issued his decision. He found that the nursing home had committed massive violations of labor law. Specifically, King David had (1) conducted illegal surveillance of employees' union activities at the Pizza Hut; (2) illegally enforced its "no Creole" rule in a discriminatory manner against known union supporters; (3) illegally fired Jean Aliza because of his union activities; (4) illegally threatened and fired Lude Duval because of her union support; (5) illegally fired Marie LaRose because of her union activity; (6) illegally created such a threatening and harassing atmosphere for Quettelie Jean-Baptiste that she had an anxiety attack resulting in a week's lost pay ("constructive suspension"); (7) illegally harassed, threatened, discriminatorily disciplined, and fired Ernest Duval because of his union support activities; (8) illegally discriminated against and fired Luders Esteril because of his union activities; (9) illegally discriminated against and fired Marie Pierre Louis because of her union activities; (10) illegally discriminated against and fired Michelle Williams because of her union activities; (11) illegally fired Carlene Dorisca because of her union activities; and (12) illegally aided District 6 while discriminatorily denying SEIU equal access to the workers. In the cases of some other workers, he did not find the employer's behavior illegal, for a variety of reasons, usually because the union and the NLRB general counsel failed to meet the full proof needed to establish guilt. ${ }^{2}$

Batson ordered the nursing home to cease its illegal activities, to post a notice admitting guilt and promising to not repeat the behavior, and to offer reinstatement and back pay (minus any money earned in the meantime) to those fired or suspended. But this was just the beginning, not the end, of the legal wrangling. King David's attorneys filed "exceptions" to Batson's rulings, contesting every single determination 
he made. At this point, almost two years had elapsed since the union election. All strong union supporters had been fired; remaining workers were frightened and were unwilling to publicly associate with the union. In addition, many of the employees at the time of the union campaign before the election had left. Swift resolution at this point would already have been "too little, too late," but the national NLRB took more than three additional years to issue its final decision and order, which upheld the vast majority of the ALJ's rulings. On August 6, 1999, the final ruling was issued.

Meanwhile, both King David and Healthcare Services went through the motions of bargaining. According to union records, sporadic and unproductive negotiations with Healthcare occurred from mid-1996 on, but negotiations with King David began only in early 1998 and then at the pace of about four to five sessions per year. However, other pressing matters were concerning the nursing home.

\section{Poor Patient Care and Threats to the Viability of the Facility}

The King David Nursing Home was also facing a crisis due to the quality of its patient care. In 1991, the Florida Agency for Health Care Administration had given it the lowest possible level (conditional) and had instituted a moratorium prohibiting further admissions until it remedied deficiencies. The facility then improved its ratings, but by May 1994, it had reverted to "conditional" status. When the facility laid off CNAs immediately after the union electoral victory, the union and the NLRB general counsel argued that this was retaliation because layoffs in the midst of a "quality care" crisis only worsened the patient care situation (NLRB general council brief, June 26, 1995).

King David again improved its rating but on December 13, 1995, was downgraded to "conditional" status with another moratorium on new admissions that lasted until May 22, 1996. On March 24, 1997, the nursing home was fined $\$ 4,762.50$ for violation of regulations and was cited again in June for eleven more violations. A few weeks later, it was sold and renamed Greenwood Rehabilitation Center. By October 1997, inspections showed that all deficiencies had been corrected (Cox 1998). But inadequate patient care continued to be a problem. Greenwood appeared on the state's April-June 1999 and July-September 1999 Nursing Home Guide Watch List because of its violations of patient care quality regulations. ${ }^{3}$ In July of 2000, it was again cited for substandard patient care. ${ }^{4}$ On October 2, 2000, the state terminated its Medicaid contracts with Greenwood and other nursing homes with the worst track records regarding patient care and service. The loss of Medicaid income of $\$ 110$ per day per resident was a staggering blow to the facility. Controversy, lawsuits, court injunctions, and the like followed, but Greenwood had been dealt a major setback (Fanous-Samaan 2000; Oppel 2000; Klas 2000; Agency for Healthcare Administration 2000a, 2000b). 


\section{Further Delays and a Final Legal Decision Supporting the Union}

Throughout 1997 and beyond, the union was unable to maintain a semblance of union life within the facility. Strong supporters had been fired for years, less overt supporters were scared and unwilling to be public, and new workers replaced a majority of the workforce who had been there at the time of the union election. The sign-in sheet of a September 11, 1997, union meeting shows an attendance of four "employees," two of whom had been fired approximately two years before. House visits were conducted to some workers' homes in December 1997, but there was no functioning union local. The sign-in sheet of a July 18, 1998, union meeting shows an attendance of five, with three of the five being fired workers Ernest Duval, Lude Duval, and Marie Pierre Louis.

In early 1998, three and a half years after the union election victory, the company and the union finally engaged in what were supposed to be substantive negotiations. The union presented a full set of proposals for a contract on January 5, 1998, and met again with company attorneys on May 15, July 10, and September 14. But the company produced no information or counterproposals.

Tactics such as meeting only infrequently, agreeing to only the most trivial issues, avoiding important substantive issues as much as possible and proposing totally unacceptable terms when forced to face them, and so on, are generally not considered a violation of the obligation to negotiate in good faith under U.S. labor law. Thus, a union facing such tactics usually has to have other sources of leverage beyond the law to prod an employer into actually negotiating contract clauses normally contained in a collective bargaining agreement. In this case, the union had no ability to apply pressure from the workforce to the company because of demoralization and fear. The union's only hope was that an eventual NLRB decision might reinstate union supporters, thus rebuilding morale and demonstrating that workers can be victorious if they stand together.

Negotiations ceased in 1999. On August 6, 1999, five years and a day after the workers voted for the union and almost three and a half years after an NLRB ALJ had ruled on illegal employer conduct, the national NLRB issued its final decision and order. With minor changes, it upheld ALJ Batson's findings of illegal employer behavior. Greenwood was ordered to end illegal conduct, to post a notice to that effect, to reinstate unjustly fired employees and to "make them whole" (undo monetary harm due to the firings), to recognize the union, and to commence bargaining in good faith (PVMI Assocs., 328 N.L.R.B. 1141).

A sense of the degree of illegal behavior the company had engaged in can be had by reading a portion of the notice it was forced to post on bulletin boards in its facility:

WE WILL NOT coercively interrogate our employees as to their own or other employees' union activities or support. 
WE WILL NOT create the impression among our employees that their union activities are under surveillance.

WE WILL NOT threaten our employees with discharge, suspension, or other unspecified reprisals because they engage in activities on behalf of the union.

WE WILL NOT promulgate or enforce a rule prohibiting our employees from conversing in their native language in order to restrict their union activities.

WE WILL NOT call our employees "troublemakers" and threaten them with discipline because they demonstrate support for the union.

WE WILL NOT interfere with our employees' attempts to engage in union activity by more closely monitoring their work activities.

WE WILL NOT threaten to, and change our employees' work schedules because they engage in union activities.

WE WILL NOT rescind previously granted schedule accommodations because our employees engage in union activities.

WE WILL NOT attempt to remove union insignia from our employees' clothing.

WE WILL NOT issue disciplinary warnings to our employees because they engage in activities on behalf of the union.

WE WILL NOT issue discharge or suspend our employees because of their membership in, or activities on behalf of, any union because they engage in activities on behalf of the union.

WE WILL NOT permit an intervening union access to our facility for union campaign purposes while denying [SEIU] access to our facility for that purpose.

WE WILL NOT in any other manner interfere with, restrain, or coerce our employees in the exercise of the rights guaranteed them by . . . the Act [the NLRA]. (PVMI Assocs., 328 N.L.R.B. 1141)

The notice promised reinstatement to fired employees, back pay and benefits (minus any earnings in the interim), and removal of any disciplinary notices from their files.

The union tried to capitalize on the favorable NLRB ruling. On September 13, 1999, union officials held a press conference with fired workers in front of the Greenwood Nursing Center. Local state representative Addie Greene and a representative of Congressman Alcee Hastings attended and spoke in support of the workers and the union. Union Director Monica Russo commented, "This decision is a major victory for workers at King David, and throughout South Florida. Their firing was illegal and shameful, and it is just as shameful that it has taken 5 years for justice to be served. But the union and these workers hung in there every step of the way. Now we use this victory to carry on our struggle for dignity, respect and justice for nursing home workers" (SEIU 1999).

In late September and early October, both Greenwood and Healthcare Services posted notices in the facility admitting guilt and promising to make amends. By midOctober, Greenwood made reinstatement offers to fired workers. By mid-January 2000, the NLRB had computed the back pay owed to those illegally fired. Money earned in the interim had to be deducted from back pay, so most amounts were minuscule: between $\$ 198$ and $\$ 7,478.52 .^{5}$ The entire bill for the back pay award 
came to $\$ 31,044.60$, a tiny cost to the employer for its illegal conduct. Years of legal bills incurred by King David and Greenwood in fighting the union had to have dwarfed this amount by many multiples.

\section{Meager Results of NLRB Ruling, Five Years Later}

Workers were offered reinstatement to a facility very different from the one they had left. Only eight workers remained from the time of the union election. Only Ernest Duval, the strongest and most stalwart union supporter, decided to return to work there. He was reinstated on December 2, 1999. According to union official Dale Ewart, "The reason only Ernest returned was simply that so many years had passed, people got other jobs, moved on with their lives, and were not willing to return to a work environment that they had every reason to believe would be hostile" (SEIU Florida Healthcare Union Secretary Treasurer Dale Ewart, e-mail message to author, February 23, 2005).

Duval immediately faced hostility, discrimination, and harassment, according to his later verbal and written statements. ${ }^{6}$ Contrary to the legal requirement of reinstatement with full seniority, he was treated as a "new hire" with no healthcare benefits until he passed a ninety-day probationary period. (Ultimately, he did receive an insurance card that was valid sixty days after his return to work.) He was paid $\$ 8.25$ per hour for a job in the hardest unit in the facility, compared to $\$ 9.00$ per hour pay to the person who replaced him after he left the job in February 2000.

Approximately a month after he returned, in January 2000, the company assigned a CNA to follow Duval, inspect his work, and question residents about his job performance. One employee told Duval that the Director of Nursing Barbara Herrick had said to watch him and other new hires because they were trying to bring in the union. On February 2, 2000, Duval was given a written disciplinary warning, allegedly for taking a break in the resident area. (Duval claimed that the break room was filthy, and therefore, few employees took their break there-other employees took breaks where he had been, and they were not disciplined.) Herrick accused Duval of trying to bring in the union and said, "I received a phone call this morning from the union. I don't care you call the union. I don't care what the union said. Don't you [know] people here don't have any interest for the union?" (written statement by Ernest Duval for union to use in filing a ULP complaint with the NLRB [hereinafter "Duval written statement"], February 2, 2000; copy in the author's possession).

Although the circumstances of his return to work were well known, Duval claimed that he had not talked to fellow employees about the union-he was hoping a contract would be signed soon, making union topics safer. Instead, his reply concerned the quality of patient care: "It's a shame to work at Greenwood—a facility [where] patient care doesn't exist! ... Every day you have to wash your patient with pillow case or the dirty night gown the patient slept with. No sheet—no pad-no 
plastic bag in the garbage can. Flies all over the patients. The soiled room-you can believe what it look like" (Duval written statement, February 2, 2000).

Two days later, Ernest Duval could no longer endure the pressure, and he submitted a written request for a leave of absence. Herrick subsequently told him he could have the leave but refused to put this in writing. Duval then said he needed six weeks off, and Herrick said OK. The union prepared an NLRB charge claiming discrimination against and harassment of Duval for union activities. The charge was filed on March 3, 2000, but was later withdrawn when it became apparent that Duval did not have the heart to continue this fight, which was destroying his emotional and family life.

With Duval gone, the union lost its last hope for any real presence in the nursing home. Negotiations were useless exercises in frustration. As noted earlier, Greenwood lost its Medicaid contract in October 2000 because of unacceptable patient care quality. The facility struggled along for awhile longer and was shut down in 2001.

The facility was reopened as Palm Beach Shores Rehabilitation and Nursing Home in 2001 by a nursing home chain with other unionized facilities. Under a "card check neutrality agreement," the union obtained recognition in April 2006 at the new facility. Negotiations began and were close to settlement when ownership reverted to the holder of the mortgage on the building in May 2007. The new owner refused to bargain and was brought before the NLRB. In November 2007, the owner agreed to bargain. On January 4, 2008, before any bargaining sessions had begun, the company announced closure of the facility. It was shut down in February 2008. However tenacious the union, it would never succeed in achieving a union contract at the nursing home facility.

\section{Analysis and Meaning of this Case}

This case is yet another example of how badly served American workers are by U.S. labor law. While the intent of the NLRA is to protect the rights of workers to freely associate, form a union, and bargain through that union, employers can thwart this purpose and actually use the law to obstruct union organizing attempts. Under the EFCA, would this case have turned out any differently? One case cannot demonstrate all of the limitations or strengths of EFCA, but it can illuminate some of both in a typical (if perhaps extreme) example of union busting. Earlier, it was hypothesized that EFCA's provisions would have aided the workers and their union, had it been the law at the time.

EFCA provides for automatic certification of the union if a majority of eligible employees sign cards or a petition stating that they desire representation by a particular union (majority sign-up or card check). This would have aided the workers' unionization efforts in this case, since union supporters had obtained signed cards 
from more than 60 percent of workers well before the August NLRB election date and possibly before the employer became aware of the union drive. The union likely would have been certified in March or April 2004, and workers would have faced either a shorter or a nonexistent period of harassment and coercion prior to union certification.

However, passage of EFCA would not automatically neutralize employer opposition, and the employer probably would have harassed, coerced, fired, and otherwise discriminated against known union supporters even with the alternative majority sign-up procedure. While coercion from the employer prior to a worker's choice would have been lessened, a postsigning union-busting campaign was still likely.

Assuming a similar union-busting campaign in either case, how would EFCA's provisions have power? EFCA would have imposed a mediation and arbitration procedure leading promptly to a first union contract on the company within ninety days following union certification if the company refused meaningful negotiations. That might have meant a union contract as of the fall of 2004. This would have been a tremendous boost to the union because a legally binding contract with "normal" union features like a grievance procedure and binding arbitration of grievances enables a union to fight back more effectively (and more promptly) against any "reign of terror" unleashed after the union victory.

However, if we assume the worst in employer behavior, the union advantages noted above may be less than they appear to be. If the employer challenged some or all signatures supporting the union, even on flimsy grounds, and then kept appealing all decisions against it through all levels of the NLRB and the courts, it may have been able to delay union certification for months or years. In that case, arbitration of a first contract would not have been triggered.

Assume a "worst case scenario": the employer refuses to accept the union certification, appealing indefinitely all negative rulings. Assume also that the employer harasses and fires union supporters, as happened in the actual case. Would EFCA's provisions have helped the workers and the unions in this case? Here, the provisions of EFCA meant to speed up the NLRB process and its penalty provisions become relevant.

The most frequently noted provisions of EFCA in this area are triple back pay for illegally fired employees (rather than simple back pay) and civil penalties of up to $\$ 20,000$ per violation. Yet it is not clear that this would have been a sufficient deterrent to the employer in this case. Assuming an unchanged pattern of firings and subsequent timing of reinstatement offers and payments, the $\$ 31,000$ in back pay would have escalated to only $\$ 93,000$, still a minor monetary cost for five years of illegal behavior and probably not enough to change the employer's cost-benefit calculation. The NLRB civil penalties would probably have been less than $\$ 20,000$ per violation, since other employers have behaved even worse.

Assume that the NLRB imposed a $\$ 10,000$ penalty per violation, adding a little over $\$ 100,000$ in additional costs to the employer. This may not have been a sufficient 
monetary cost to deter the employer from its union-busting campaign. One lesson from this case is that EFCA's triple-back-pay provisions would more effectively protect high-wage workers than low-wage workers like those in this case, simply because tripling high wages can be expensive whereas tripling low wages is not.

EFCA's least-remarked-upon feature mandates that the NLRB must give highest priority to immediately investigating and moving against suspected employer discrimination, threats, spying, and other forms of coercion against employees during an organizing drive or before a first contract. Yet this feature would have been critical in this case, mainly because it would have sped up the process greatly. The five-year delay between the union election and the final NLRB order to bargain was crucial to the success of the union-avoidance effort. If fired workers were returned to their jobs within months instead of years, more of them likely would have come back, and the union would have been much more likely to retain a presence within the facility. Likewise, highest priority NLRB investigations might have led to temporary restraining orders or injunctions against repeated employer misconduct.

Determining the likely effect of EFCA's provisions to speed up (and potentially stiffen through injunctive relief) NLRB response to employer interference is a somewhat speculative endeavor. If we assume that the five-year delay in this case would have been reduced to two years or less and that restraining orders or legal injunctions might have been forthcoming within that two-year period, the assistance to the union would have been huge. But if the process continued to bog down in delay or if the NLRB proved unwilling to aggressively seek restraining orders and injunctions, this provision of EFCA may not have been that helpful. It is safe to say that the process would have been more rapid under EFCA, but it is difficult determine by how much.

Thus, speeding up the process becomes central to a determination of how much EFCA would aid workers and their unions in cases such as this. By potentially speeding up the process, triggering union recognition more rapidly, achieving a first union contract shortly thereafter, and possibly curbing employer firings and intimidation because of the shorter time periods, EFCA provisions could greatly bolster worker efforts to obtain collective representation through a union. It thus appears to be a fairly well-crafted legal initiative to address a number of the most egregious employer violations of workers' rights in union organizing drives, at least those similar to the one chronicled here. ${ }^{7}$

Loopholes for antiunion behavior by employers would still exist after EFCA was passed. For example, EFCA's provisions kick in only after a union organizing drive has commenced. This may induce antiunion employers to do their intimidation or "persuasion" well before any organizing drive commences. But diffuse efforts of this nature would certainly be less focused and more difficult and expensive than current union-busting campaigns. Therefore, they would likely be less powerful or effective.

This case points to ways that EFCA could be improved. It could, for example, require that union certification not be postponed by any employer appeals; if those appeals are successful the earlier certification would be revoked, but it would have 
been in place in the meantime. That provision, coupled with the provision for arbitration of a first contract, would virtually guarantee a union contract promptly after a majority of workers sign up for the union. A mandatory requirement for the NLRB to seek a restraining order or court injunction when it finds employer interference with employees' rights during a union drive or before a first contract would also strengthen EFCA. And larger civil penalties for employer interference with employee choice could strengthen the act's deterrent effect on employer behavior, especially for low-wage workers.

Skeptics are undoubtedly correct that passage of the EFCA would not by itself resolve all major obstacles to union organizing success. For that, a major cultural shift in the country concerning workers' rights and the legitimacy of employer interference in those rights would be necessary. However, given the culture of the United States today and given the predisposition of American employers to egregiously interfere in their employees' choices regarding unionization, it is clear that EFCA would provide a powerful regulatory change that would make the exercise of the uncoerced right to choose a union more of a reality. EFCA could be improved upon, but it would be a giant step forward even without any improvements.

\section{Appendix}

\section{Chronology of the Unionization Attempt}

Date (shaded by year)

July-Dec. 1993

Jan.-Feb. 1994

Feb. 25, 1994

April 21, 1994

Late May 1994

Late May 1994

Early July 1994

July 1994

Late July-early Aug. 1994

Aug. 1, 3, 1994

Aug. 5, 1994

Aug. 6, 13, 1994

Aug. 14, 1994

Late Aug. 1994
Event

Employees secretly begin union organizing drive; go public in Dec.

Union supporters Aliza, Esteril, LaRose, Dorisca, and Lude Duval harassed and threatened for supporting union.

Union supporter Aliza fired on a pretext.

Union supporter Lude Duval fired in discriminatory manner.

Union supporter LaRose fired on a pretext.

Employer issues new rule against speaking Haitian Creole on the job.

Union supporter Ernest Duval "setup" twice by employer to prove nonexistent misconduct.

Union supporter Jean-Baptiste threatened three times for union support.

Union supporter Exile pressured to vote "no," promises to do so.

Union leader Ernest Duval disciplined twice in "setup" incidents.

Union election held. Union wins.

Ernest Duval written up and fired using pretexts.

Union supporter Jean-Baptiste has "anxiety attack" due to management intimidation; loses a week's work and pay as a result.

Union supporter Esteril fired on a pretext. 


\section{Appendix (continued)}

\begin{tabular}{|c|c|}
\hline Date (shaded by year) & Event \\
\hline Nov. 9, 1994 & Union supporter Pierre Louis fired on a pretext. \\
\hline Nov. 11,1994 & Union supporter Williams fired on a pretext. \\
\hline Dec. 3, 1994 & Union supporter Dorisca fired on a pretext. \\
\hline Feb.-March 1995 & $\begin{array}{l}\text { Hearings by an Administrative Law Judge (ALJ) of the NLRB } \\
\text { on election validity and employer misconduct. }\end{array}$ \\
\hline Aug. 3, 1995 & ALJ rules election valid; certifies the union. Employer appeals. \\
\hline Feb. 29, 1996 & $\begin{array}{l}\text { ALJ find massive employer violations; orders workers to } \\
\text { be reinstated. Employer appeals. }\end{array}$ \\
\hline April 1997 & $\begin{array}{l}\text { Facility sold and renamed after being repeatedly cited and } \\
\text { fined for poor quality care. }\end{array}$ \\
\hline 1998 & $\begin{array}{l}\text { Four fruitless attempts at "negotiation" during year; employer } \\
\text { refuses to grant anything of substance. }\end{array}$ \\
\hline Aug. 6, 1999 & $\begin{array}{l}\text { Final ruling by national NLRB. Upholds most of ALJ's rulings; } \\
\text { finds massive employer violations. Certifies union, orders } \\
\text { reinstatement of fired workers, and orders bargaining. }\end{array}$ \\
\hline Mid-October 1999 & $\begin{array}{l}\text { Fired workers offered reinstatement; only Ernest Duval accepts; } \\
\text { begins work in December } 1999 .\end{array}$ \\
\hline Early Feb. 2000 & Ernest Duval quits after facing discrimination, surveillance, etc. \\
\hline 2001 & Facility closed and reopened under yet another name. \\
\hline 2006 & $\begin{array}{l}\text { Union wins recognition under a "card check neutrality" } \\
\text { agreement. }\end{array}$ \\
\hline 2007 & $\begin{array}{l}\text { Facility changes ownership; new owner refuses to bargain. In late } \\
\text { 2007, agrees to bargain under threat of NLRB action. }\end{array}$ \\
\hline Jan. 4, 2008 & Facility closed for good. Union never achieves a first contract. \\
\hline
\end{tabular}

\section{Notes}

1. Administrative Law Judge (ALJ) Batson later (February 29, 1996) determined this suspension for a week to be an "unlawful constructive suspension," meaning that the suspension from work and loss of pay was due to the illegal and intolerable treatment of Jean-Baptiste that caused the incident in the first place. Batson therefore ordered that she receive back pay for the missing week of work. In a much later final ruling (August 6, 1999), the national NLRB reversed this part of Batson's ruling because the employer's behavior, while illegal, was not found to be "intolerable."

2. ALJ Batson's decision, dated February 29, 1996, is attached to the final determination of the case by the national NLRB, dated August 6, 1999. In its final ruling, the NLRB overturned the finding of illegal surveillance at the Pizza Hut because it was possible that Caprisecco and Megill just happened to be five feet from the union meeting while they were on lunch break and that their prolonged, one-and-a-halfhour stay without receiving any food was merely coincidental. It also overruled the "constructive suspension" charge that the nursing home had caused Quetellie Jean-Baptiste's anxiety attack and her subsequent loss of a week's pay, because its treatment of her, while illegal, did not rise to the level of being intolerable.

3. Information taken from the state's Nursing Home Guide Watch List for these two periods, which was on the Web for thirty months, is no longer accessible because of updating the Web site.

4. Information taken from the state's Nursing Home Guide Watch List for July through September 2000 , which was on the Web for thirty months, is no longer accessible because of updating the Web site. 
5. Actual amounts were as follows: Michelle Williams, $\$ 198$ (5-year period); Jean Aliza, $\$ 1,793.13$ (almost 6-year period); Ernest Duval, \$1,797.58 (5 1/4-year period); Lude Duval, $\$ 3,801.88$ (5 1/2-year period); Luders Esteril, \$4,665.96 (5 1/4-year period); Marie LaRose, \$5,144.13 (5 1/2-year period); Marie Pierre Louis, \$6,165.40 (5-year period); and Carline Devila (formerly Carline Dorisca), \$7,478.52 (almost 5-year period).

6. The following account will consist of allegations made by Ernest Duval-they were not verified by subsequent NLRB officials because Duval became so discouraged that he left Greenwood's employ and decided not to pursue unfair labor practice (ULP) charges that the union was preparing. Therefore, we do not have a government document proving these claims, as we do with the government's earlier findings validating all of Duval's testimony. However, Duval had been found to be a credible witness in all previous testimony before government officials; his claims here appear to the author to be credible. The facts in the following paragraph are taken from a written statement by Ernest Duval, notes taken by union officials who interviewed him, and charges stated in an ULP charge the union prepared but never delivered because Duval got discouraged and gave up the fight.

7. Counterfactual analysis is always somewhat speculative, of course, meaning that the evidence from this case of EFCA's likely efficacy is far from definitive. However, "worst case" assumptions as well as more optimistic ones were used to guard against a tendency to minimize obstacles to EFCA effectiveness and thus to find support for the hypothesis put forth earlier in the article.

\section{References}

Adams, Roy. 2007. The Employee Free Choice Act: A skeptical view and alternative. Labor Studies Journal 31 (4): 1-14.

Agency for Healthcare Administration (Florida). 2000a. Agency responds to judge's ruling on Medicaid action. Press release, October 11.

Agency for Healthcare Administration (Florida). 2000b. AHCA transfer of nursing home residents goes smoothly. Press release, October 13.

Bronfenbrenner, Kate. 1994. Employer behavior in certification elections and first contract campaigns: Implications for labor law reform. In Restoring the promise of American labor law, ed. Sheldon Friedman, Richard W. Hurd, Rudolph A. Oswald, and Ronald L. Seeber, 75-89. Ithaca, NY: Cornell University Press.

Brudney, James J. 2005. Neutrality agreements and card check recognition: Prospects for changing paradigms. Iowa Law Review 90:819-86.

Comstock, Phil, and Maier B. Fox. 1994. Employer tactics and labor law reform. In Restoring the promise of American labor law, ed. Sheldon Friedman, Richard W. Hurd, Rudolph A. Oswald, and Ronald L. Seeber, 90-109. Ithaca, NY: Cornell University Press.

Cox, John W. 1998. State pulls surprise inspections on troubled nursing homes. South Florida Business Journal, January 30, 1998 (accessed March 11, 2005, but no longer available).

Dickens, William. 1983. The effect of company campaigns on certification elections: Law and reality once again. Industrial and Labor Relations Review 36 (2): 560-75.

Eaton, Adrienne, and Jill Kriesky. 2001. Union organizing under neutrality and card check agreements. Industrial and Labor Relations Review 55:42-59.

Fanous-Samaan, Sarah. 2000. AHCA terminates nursing home Medicaid contracts. Tampa Bay Business Journal, October 2, 2000. http://www.bizjournals.com/tampabay/stories/2000/10/02/daily1.html?t=printable (accessed August 18, 2008).

Freeman, Richard, and James Medoff. 1984. What do unions do? New York: Basic Books.

Friedman, Sheldon. 2007. Why the Employee Free Choice Act deserves support: Response to Adams. Labor Studies Journal 31 (4): 15-22. 
Godard, John. 2002. Institutional environments, employer practices, and states in liberal market economies. Industrial Relations 41:249-86.

Godard, John. 2003. Do labor laws matter? The density decline and convergence thesis revisited. Industrial Relations 42:458-92.

Gross, James. 1995. Broken promises: The subversion of American labor law, 1947-1994. Philadelphia: Temple University Press.

Kaufman, Bruce, and Paula Stephan. 1995. The role of management attorneys in union organizing. Journal of Labor Research 16:439-54.

Klas, Mary Ellen. 2000. Nursing home list conflicts, confuses. Palm Beach Post, October 10, 1A.

Kleiner, Morris. 2001. Intensity of management resistance: Understanding the decline of unionization in the private sector. Journal of Labor Research 22:519-40.

Kochan, Thomas, Harry Katz, and Robert McKersie. 1986. The transformation of American industrial relations. New York: Basic Books.

Lafer, Gordon. 2008. What's more democratic than a secret ballot? The case for majority sign-up. Working USA 11:71-98.

Lawler, Edward. 1984. The influence of management consultants on the outcome of union certification elections. Industrial and Labor Relations Review 38:388-51.

Lawler, Edward. 1990. Unionization and deunionization. Columbia: University of South Carolina Press.

Logan, John. 2002. Consultant, lawyers and a the "union free" movement in the United States since the 1970s. Industrial Relations Review 33 (3): 197-214.

Logan, John. 2006. The union avoidance industry in the United States. British Journal of Industrial Relations 44 (4): 651-75.

Martinez Ortega, Julie. 2007. Why we should support the Employee Free Choice Act. Labor Studies Journal 31 (4): 23-30.

Nissen, Bruce. 1998. Fighting the union in a "union-friendly" company: The AT\&T/NCR case. Labor Studies Journal 23 (3): 3-33.

Oppel, Shelby. 2000. 6 nursing homes lose contracts. St. Petersburg Times, October 3, 1B. http://pqasb .pqarchiver.com/sptimes/access/62050866.html dids $=62050866 \&$ FMT $=F T \& F M T S=A B S: F T \& t y p e=$ current\&date $=\mathrm{Oct}+3 \% 2 \mathrm{C}+2000$ \&author $=$ SHELBY + OPPEL\&pub=St.+Petersburg+Times\&edition= \&startpage $=1 . B \& d e s c=6+$ nursing + homes + lose + contracts (accessed August 18, 2008).

Service Employees International Union (SEIU). 1999, September 10. Press release of SEIU Florida Healthcare Union publicizing a September 13, 1999, press conference. (Copy in the author's possession.)

Stewart, J. Hamilton. 2006. Neutrality and card check agreements: Union assaults on employee rights and the integrity of the National Labor Relations Board. Journal of Labor Research 24 (4): 443-72.

U.S. Department of Labor. 2002, March 21. Media release: New York District 6 health and pension plan officials sued over plan expenses. http://www.dol.gov/ebsa/newsroom/pr032102.html (accessed August 18, 2008).

U.S. Department of Labor. 2004, September 28. Media release: Labor Department obtains consent judgment restoring $\$ 50,000$ to New York union's health and pension plans. http://www.dol.gov/ebsa/ newsroom/pr092804.html (accessed August 18, 2008).

Weiler, Paul. 1990. Governing the workplace: The future of labor and employment law. Cambridge, MA: Harvard University Press.

Bruce Nissen (nissenb@fiu.edu) is the director of research at the Center for Labor Research and Studies at Florida International University, where he also directs the Research Institute on Social and Economic Policy (http://www.risep-fiu.org). 